https://doi.org/10.48009/1_iis_2007_154-159

\title{
EXPLORING THE EVOLUTION OF IS EDUCATION: A COMPREHENSIVE CURRICULUM REVIEW
}

\author{
Dr. Sean T. McGann, Ohio University, mcgann@ohio.edu
}

\begin{abstract}
The study of the evolution of IS curricula over the past four decades provides an interesting perspective on the progression of the IS discipline as it comes of age. Through a comparison of IS curriculum "ideals" put fourth by the IS academic community (ACM/AIS Curriculum Committee recommendations) and a sample of general IS texts, which represent "actual" curriculum designs, the nature of the development of IS education over time is shown. In this process, I identified 3 primary areas of emphasis in the scheme of IS curriculum design: Technical/Specialized, Organizational/Society, Strategic/Management. In tracing the evolution of the curriculum design in these areas, I saw the emphasis shift from general technical skills in the 1970s to the addition of organizational skills in the 1980s and finally to a more integrated model emphasizing all three areas more equally by the late 1990s to the present. There was also an apparent relationship between the "ideal" designs of the ACM Committee and the "actual" curriculum suggested by the texts. Further research is needed to specify the nature of these correlations.
\end{abstract}

Keywords: IS curriculum evolution, IS education, IS textbooks, AIS/ACM Curriculum

\section{INTRODUCTION}

Past studies of information systems education have concluded that there is a disparity between the needs of the IS industry and what is offered in IS curricula [1]. This is purportedly due to the changing nature of the IS profession, which requires a rapidly evolving mix of skills. This study explores the balance of emphasis on technical, organizational and managerial skills in IS curricula, and examines how it has evolved over time. A key benchmark for the study of this evolution is the reporting process that is undertaken twice each decade by the IS Curriculum Committee, which is a joint effort of ACM, AIS, DPMA and ICIS. This committee issues a detailed set of guidelines every 5-10 years, which provides an overview of the current IS environment and outlines a plan of action for
IS education to satisfy its requirements. In examining these reports, as well as other substantive literature over the past 4 decades, I identified a pervasive theme of how to best strike the balance in various skill areas in the design of IS curricula. The solutions proposed have changed significantly over time. My review shows that in the initial stages of IS curricula design in the 1970s, the recommendation was to separate these areas into discrete concentrations [2]. However, that position has certainly changed as the literature now prescribes a more progressive design, which is focused on creating a balanced IS professional. The current trend outlined by researchers is that of teaching a holistic set of skills [3], and most importantly putting emphasis on integration of these skills to assure readiness for the IS profession [4]. The recurring question of how best to design the appropriate skill mix into IS curricula seems to indicate that it is an important area for research in IS education, and one where I seek to make a contribution through this paper.

\section{LITERATURE REVIEW}

Although researchers seem to agree that IS education is an important topic, aside from the recommendations of the IS curriculum committee mentioned above, it has received minimal coverage in top journals. Publications such as Management Information Systems Quarterly and Information Systems Research are publishing articles regarding IS curriculum, but they are few in number. In the articles I reviewed it was apparent that over the past 30 years, research acknowledges that this area has a significant impact on the IS field, and has called for more attention to it. However, these articles are primarily conceptual, with very few empirical studies that further understanding and development of norms in this area. Further, these articles have been published infrequently (e.g. every 5-10 years in MISQ), which is not consistent with their alleged level of importance.

Articles related to IS curricula have dealt with such areas as current proposals for reform [5], 
and the identification of core skills that need to be emphasized in order to effectively prepare IS professionals [6-8]. As mentioned above, a key theme is exploring what types of knowledge and skills should be emphasized in courses of study in order to best prepare students for IS Careers. A core issue is the comparison of the goals of IS programs with the level of technical "hard" skills vs. conceptual "soft" skills that are considered appropriate to meet industry expectations [8]. Conclusions from previous studies show that in the past 10 years, the focus has been primarily on the teaching of technical specialties, and not enough on the balance of organizational and managerial skills [9]. I also discovered concern regarding the lack of integration of the skills in these diverse areas. This problem was attributed to the fact that IS courses are typically taught independently with no central curriculum model to integrate them $[4,10]$.

\section{RESEARCH METHODS}

Utilizing the ACM, AIS Curriculum Models, which I refer to as "ideals" of IS curriculum [2, 3, 11-13], I established a benchmark framework for each time period, which consisted of the following broad categories:

- Technical Areas - programming, database, networking, Internet technologies, client server and telecommunications

- Strategic/Management Areas - systems development and implementation, requirements solicitation, IS project management, systems integration

- Social/Organizational Areas organizational change management, IS human resources management issues, societal impacts of IS
The "ideal" models were then compared in the framework to "actual" curriculum data from IS texts. The contents of 9 renowned general IS textbooks published between 1974 and 2007 were used as a representative sample of the actual components of IS curricula [14-22] in those eras. I established that these texts were appropriate through recommendations by senior professors from the IS Department at Case Western Reserve University [23]. I assumed that there is a correlation between the contents of the texts examined and the design of core IS curricula. The table of contents of each text was scanned into a word document and codified, using multiple researchers to assure validity. Codification consisted of mapping text sections to the three framework categories mentioned above to establish a count of matches in each category. The number of matches was considered to be an indication of alignment between "ideal" and "actual" IS curricula. I also took key concepts from the ACM models and texts, sorted by decade and compared them side-by-side to deepen the analysis.

\section{RESULTS}

Counts of matches are shown in Figure 1 below. The figure shows the rapid evolution of all three category areas into the early 1990s, as the IS discipline began to mature. There is then a decline in the technical area, with a more moderate decline across the other areas in the late 1990s. In the 2000s, I found an initial upward trend across all areas, behind the momentum of the Internet revolution. However, it seems that there was a steady decline in technical emphasis as the IS discipline differentiated itself with its emphasis on strategic and organizational areas. Table 1 shows a qualitative comparison of ACM model and text data. 


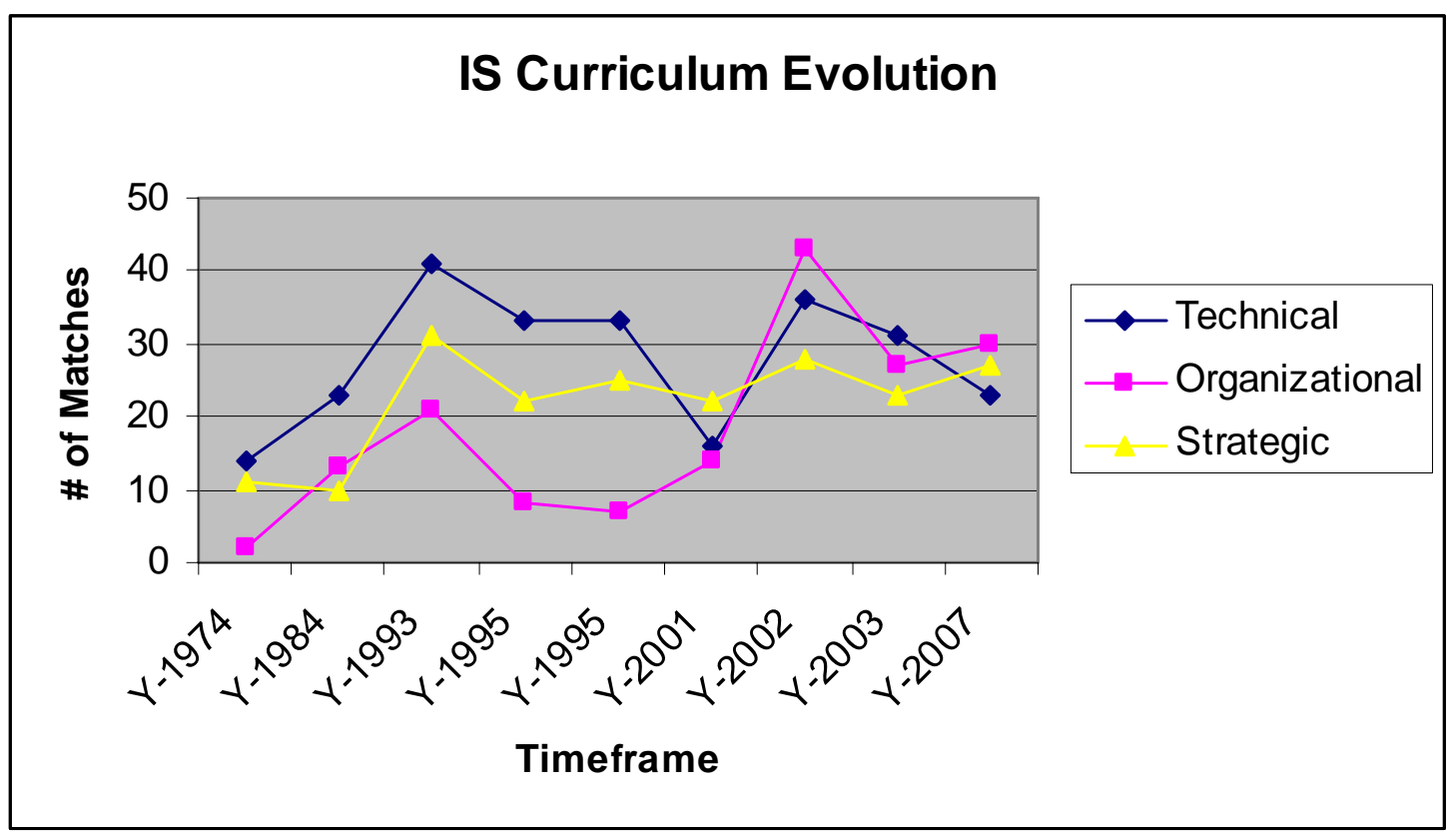

Figure 1

\section{Ideal vs. Actual Comparisons}

The following section uses counts from Figure 1 above and qualitative data from Table 1 below to summarize "ideal" vs. "actual" comparisons in each decade of the study.

\section{0s Comparison}

The "ideal" vs. "actual" comparison in this timeframe shows relatively few matches, with a primary emphasis on technical content. The key differences come first in the area of IS strategy, which was not recommended at all in this era's ACM curriculum model, but received high coverage in the IS text. The other disparity is with organizational/societal themes. In the model, this area was emphasized, but in the text, it was only covered at a cursory level.

\section{0s Comparison}

In the 1980s, my data showed that as the IS field evolved so did the ACM model and the curriculum designs indicated through text data. Both sides showed a significant increase in depth of specific technologies and methodologies covered. It seems that, as in the previous timeframe, the technical "ideal" and "actual" are in synch. Also, organizational areas are similar, with mutual emphasis on integration of different organizational skills with technical areas. However, from a managerial/strategic standpoint, there is some disparity. Although management is called for during this timeframe in the ACM model, course content in for this area in the text is minimal. Further, IS strategy is not even suggested as an ACM course category. In contrast, the text data for this timeframe shows a significant emphasis on both management and strategy. Although there seems to be more overall balance in this timeframe, it is mostly in the technical and organizational areas.

\section{0s Comparison}

In this timeframe, as the IS field matured, so did the quality of the design of IS curricula. The ACM model is more balanced than the previous two, with significant emphasis in all three areas. As in the previous two designs, there is a slightly higher level of focus on technical courses. Texts reviewed show a similar improvement and balance, as extensive coverage is given to specific technologies, organizational issues and IS strategy. Again in this case, the comparison between ACM designs and texts shows that the texts emphasize strategic issues more, while the curriculum models emphasize organizational issues.

\section{0s Comparison}

In this final timeframe, the comparison of "ideal" and "actual" curriculum designs is similar to the previous timeframe, with the exception of changes which seemed to be driven by the diffusion of the Internet and eBusiness. The consistent emphasis on technology by both was still present. Also the disparity in emphasis on organizational and strategic areas was apparent, 
but seemed to have narrowed. Both the ACM model courses and texts changed to reflect the effects of the Internet, incorporating Internet technology, organizational effects of the Internet, eBusiness strategy and IT security material. This timeframe's comparison shows the ideal and the actual to be the most closely correlated.

In Table 1 below, information from the previous sections is summarized as follows:

Table 1

\begin{tabular}{|c|c|c|}
\hline Timeframe & Ideal & Actual \\
\hline 1970s & $\begin{array}{l}\text { - Early stages of IS discipline } \\
\text { - Lack of strong recommendations } \\
\text { - IS course work was "supplemental" } \\
\text { - No specific technologies or } \\
\text { methodologies } \\
\text { - Emphasis on IS basics/fundamentals } \\
\text { - Clear division between organizational } \\
\text { and technical courses (Either/Or) } \\
\text { - Lack of course integration and depth }\end{array}$ & $\begin{array}{l}\text { - Emphasis on technical and strategic } \\
\text { materials } \\
\text { - General concepts of systems theory, } \\
\text { systems design and data modeling } \\
\text { - Organizational/ social areas received low } \\
\text { level of coverage }\end{array}$ \\
\hline 1980s & $\begin{array}{l}\text { - Significant progress in IS discipline } \\
\text { - IS-specific careers and skills in demand } \\
\text { - Integration of organizational and } \\
\text { technical courses into single path } \\
\text { - Specific technologies prevalent } \\
\text { - More focus on design and } \\
\text { methodologies, and less on technical } \\
\text { - Integration of management skills, } \\
\text { communication, writing and behavioral } \\
\text { skills in the context of organizations }\end{array}$ & $\begin{array}{l}\text { - High coverage in all areas } \\
\text { - Specific technologies, such as types of } \\
\text { programming languages, networks, } \\
\text { operating systems, and databases } \\
\text { - Methodologies for development and } \\
\text { implementation of systems } \\
\text { - Consistent depth in organizational areas } \\
\text { with emphasis on human resources } \\
\text { - IS management and strategy coverage } \\
\text { high } \\
\text { - Impacts of IS on society emphasized }\end{array}$ \\
\hline 1990s & $\begin{array}{l}\text { - IS discipline begins to mature } \\
\text { - Technology evolved along with need } \\
\text { for technical skills } \\
\text { - Greatly increased scope and depth of } \\
\text { model } \\
\text { - Model included communications, } \\
\text { interpersonal relationships, } \\
\text { management, IT and tools, computer } \\
\text { apps, and system development } \\
\text { methodologies } \\
\text { - High level of emphasis on specific tools } \\
\text { and methodologies } \\
\text { - Increased emphasis on integration of } \\
\text { skills in technical, managerial and } \\
\text { organizational areas }\end{array}$ & $\begin{array}{l}\text { - Significant increases in coverage in the } \\
\text { areas of database, networking/hardware, } \\
\text { Internet technologies, and } \\
\text { applications/programming } \\
\text { - Dramatic increases in organizational and } \\
\text { societal coverage, focus on impacts } \\
\text { - Ethics make its debut, but not covered } \\
\text { extensively } \\
\text { - Management and strategy showed } \\
\text { emphasis on IS strategy and IS Cross } \\
\text { Functional Concepts }\end{array}$ \\
\hline
\end{tabular}

\section{DISCUSSION AND CONCLUSION}

In general, my analysis showed that over time, the "ideals" put fourth by the ACM curriculum committee became increasingly similar to what was actually being designed into the texts of IS curricula. There were areas of discrepancy in the 1970s, as the ideal called for technical and organizational emphasis and the actual design reflected technical and strategic emphasis. However, this was rectified from the 1990s on.

Through my study, I identified a number of interesting patterns in IS curriculum evolution and possibilities for future research in IS education. Initially, I showed a timeline of the evolution of the IS discipline over the past four 
decades. As an IS educator, it was interesting to trace development of the field as it established its identity and became an increasingly viable course of study.

Further research is needed to more rigorously quantify the relationship between ACM/AIS models and actual IS curricula to examine the specifics of the relationship. This research suggests that the possibility of such a correlation exists. However, a larger sample of texts would need to be utilized in a more extensive study in order to draw this conclusion. Further, this study relies on the comparison of qualitative data ("ideals") and quantitative data ("actuals"). A future study may need to find an approach for quantifying the ideals of the curriculum committee, or some other source of quantitative "ideal" data to facilitate a more rigorous study. Specifically, I propose the following research questions for further study:

- Does the evolution of IS curriculum models eventually shape IS texts, through the input of the ACM committees?

- Do ACM curriculum designs impact the actual design of IS curricula?

- Do IS texts impact the design of IS curricula?

- Do IS curricula impact the design of IS texts?

- What are the other factors that influence IS curriculum development (e.g. the business environment, the IS industry, etc.) along technical, organizational and managerial lines?

Addressing the above questions would help IS educators understand what influences the evolution of IS curricula. This understanding would assist IS Departments in making decisions on whether to channel resources to forums such as ACM/AIS to help influence IS curriculum and text trends, or help identify other means of influencing curriculum development. It would also help us to understand why IS curricula and the IS discipline have evolved in each of its primary areas in the past. This competency will enable us to better predict curriculum trends and become proactive in the development of more relevant IS curricula.

\section{REFERENCES}

1. Sahraoui, S., Is IS education value neutral? Journal of Computer Information Systems, 1998. 38(3): p. 105-109.

2. Couger, J.D., Davis, Gordon, Curriculum Recommendations for Undergraduate Programs in IS. Communications of the ACM, 1973. 16(12): p. 727-749.

3. Davis, G., Couger, J. Daniel, IS '95: Guidline for IS Curriculum. MIS Quarterly, 1995. 24(11): p. 341.

4. Gorman, B.C., Core Competencies in IS Education. New Library World, 2002. 103(1182): p. 436-445.

5. Marshall, J., Information on Information: Recent Curriculum Reform. Studies in Philosophy and Education, 1998. 17: p. 313321.

6. Wong, E.Y.W., The education and training of future IS professionals in Hong Kong. Education and Training, 1996. 38(1): p. 3743.

7. Zack, M., An MIS Course Integrating IT and Organizational Issues. The Database for advances in IS, 1998. 29(2): p. 73-87.

8. Trauth, F., The Expectation Gap - Industry Expectations Versus Academic Preparation. MIS Quarterly, 1993. 17(3): p. 293-307.

9. Gill, Q.H., Information Systems Education in the USA. Education and Information Technologies, 1998. 3: p. 119-136.

10. Gupta, R.W., A Capstone Course in the IS Curriculum. International Journal of Information Management, 1998. 18(6): p. 427-441.

11. Couger, J.D., Davis, Gordon, IS Curriculum Recommendations for the 80s. Communications of the ACM, 1982. 25(11): p. 781.

12. Davis, G., Gorgone, John, Valacich, Joseph, IS 2002: Final Report of the Undergraduate IS Model Curriculum. 2002 ICIS Proceedings, 2002: p. 923-931.

13. Gorgone, G., Stohr, Valacich, Wigand, MSIS 2006 Currculum Preview. CAIS, 2006. 15: p. 544-554.

14. Kroenke, D., Using MIS. 2007: Prentice Hall.

15. Glans, T., Grad, B, Holstein, D, Mangement Systems. 1974, NYC: Holt, Reinhart and Winston, Inc.

16. Hicks, J., MIS: A User Perspective. 1984, NYC: West Publishing.

17. Hicks, J., MIS: A User Perspective. 1993, St Paul, Minn: West Publishing. 
18. Schultheis, R., Sumner, M, MIS: The Manager's View. 1995, Chicago: Irwin.

19. Nickerson, R., Business Information Systems. 1998, NYC: Addison-Wesley.

20. Haag, MIS for the Information Age. 2001, Boston: Mcgraw Hill.

21. Stair, R., Reynolds, G, Principles of Information Systems. 2002, USA: Thomson Learning.

22. Jessup, L., Valacich, J., Information Systems Today. 2003, Upper Saddle River, NJ: Prentice Hall.

23. Collopy, F.B., R.; Lyytinen, K; , MIDS 527 project discussions. 2002-2007: Cleveland, Ohio. 